ISSN : $2406-7415$

e-ISSN : $2655-9919$

JURNAL AKUNTANSI DAN BISNIS KRISNADWIPAYANA

DOI: http://dx.doi.org/10.35137/jabk.v7i3.448

Vol. 7 No. 3 (September - Desember) 2020

\title{
ANALISA PENGAKUAN PENDAPATAN PROYEK DAN BIAYA PROYEK SERTA PPH PASAL 4 AYAT 2 PADA LAPORAN KEUANGAN PT ADHI KARYA (PERSERO) Tbk. PROYEK RS SANTO BORROMEUS GEDUNG ELIZABETH
}

\author{
Iwan Ardiawan ${ }^{1}$ \\ ${ }^{\mathbf{1}}$ Fakultas Ekonomi Universitas Krisnadwipayana \\ Jalan Unkris Jatiwaringin Jakarta Timur \\ Herry Winarto ${ }^{2}$ \\ ${ }^{2}$ Fakultas Ekonomi Universitas Krisnadwipayana \\ Jalan Unkris Jatiwaringin Jakarta Timur \\ email: herrywinarto45@yahoo.com
}

\begin{abstract}
The research of this research is to know the treatment of income and expenses as well as income tax article 4 paragraph 2 in PT Adhi Karya (Persero) Tbk. In accordance with PSAK No. 34. This research method uses qualitative research, namely the results of research in the form of descriptive data that can be accounted for. According to PSAK No. 34, contract revenue related to construction contracts should be recognized as income with due regard to the stage of completion of contract activity at the balance sheet date. PT Adhi Karya (Persero) Tbk determines revenue recognition using the Completion Percentage Method. The accounting bookkeeping method is on an accrual basis, namely revenue is recorded or recorded at the time the transaction is made. The recording of Income Tax Article 4 paragraph 2 can only be reduced after the company receives proof of withholding from the owner.
\end{abstract}

Keywords: Income and fees as well as Income Tax Article 4 paragraph 2

\section{PENDAHULUAN}

Pengakuan pendapatan dan biaya harus menggunakan akrual basis agar mendapatkan keaadaan yang sebenarnya tetapi pendapatan termyn di proyek akan dikenakan Pajak Penghasilan Pasal 4 ayat 2 dan pemotongan itu akan bisa diakui sebagai pengurang dari pendapatan jika owner/ pemberi kerja sudah menyerahkan bukti potongnya. Selama pemberi kerja belum memberikan bukti potongnya maka laba perusahaan akan besar, Karena masih ada Pajak tangguhan PPh Ps. 4 ayat 2 dibulan sebelumnya. Pelaporan pendapatan suatu perusahaan biasanya dilaporkan pada saat akhir periode akuntansi baik bulanan, kwartal, semester, atau tahunan. Pendapatan yang disajikan dalam Laporan Keuangan merupakan pendapatan yang telah terhimpun dan terealisasi.
Pendapatan yang telah terhimpun ditandai dengan berlakunya waktu sebagai pengakuan pendapatan pada periode tertentu. Sedangkan realisasinya ditandai dengan adanya aktiva baru (kas atau piutang). Pendapatan harus dilaporkan pada waktu ketidakpastian dapat dikurangi sampai tingkat yang dapat ditolerir.

Dalam hal pencatatan Pajak Penghasilan Pasal 4 ayat 2 tidak bisa langsung dicatat sebagai pengurang pendapatan karena Pajak Penghasilan Pasal 4 ayat 2 baru bisa diakui jika PT Adhi Karya (Persero) Tbk telah menerima bukti potong dari pihak pemberi pekerjaan proyek (Owner). Oleh sebab itu pseneliti ingin melakukan penelitian tentang seberapa besar pengaruhnya terhadap Laporan Keuangan. 


\section{LANDASAN TEORI}

\section{Pengertian Pendapatan}

Pendapatan satu dari sekian banyak hal yang menjadi perhatian di setiap perusahaan, karena dalam seluruh aktivitas perusahaan bertujuan untuk memperoleh pendapatan semaksimal mungkin. menurut Ardiyos (2016), pendapatan diartikan dalam bidang akuntansi artinya lebih luas, yaitu suatu kenaikan atau tambahan dalam aktiva-aktiva dari suatu perusahaan karena operasi-operasi yang berhasil dalam suatu periode tertentu. Dengan kata lain pendapatan (income) adalah kelebihan pendapatan atau revenue atas beban dan kerugian yang terkait dalam operasi perusahaan pada suatu periode tertentu.

\section{Konsep Pendapatan}

Di dalam kepustakaan akuntansi ada dua pendekatan yang mendasari konsep pendapatan. Pendekatan pertama berfokuus pada aliran masuk aktiva sebagai hasil kegiatan operasi perusahaan. Sementara itu pendekatan kedua berfokus pada penciptaan barang atau jasa oleh perusahaan serta penyalurannya kepada konsumen atau produsen lainnya. Dari kedua pendekatan ini muncul beberapa definisi pendapatan.

\section{Pengertian Penjualan}

Menurut Arens, Elder dan Beasley (2014) menyatakan bahwa, penjualan merupakan prosses yang diperlukan untuk pengalihan kepemilikan atas barang dan jasa yang telah tersedia untuk dijual kepada pelanggan". V. Wiratna Sujarweni (2015) mengatakan penjualan adalah sistem kegiatan pokok perusahaan untuk memperjualbelikan barang dan jasa yang perusahaan hasilkan. Menurut Thamrin
Abdullah dan Francis Tantri (2012) Penjualan adalah bagian dari promosi dan promosi adalah bagian dari keseluruhan sistem pemasaran.

\section{METODE PENELITIAN}

Metode analisa yang digunakan dalam penelitian ini adalah metode deskriptif, yaitu dengan cara menganalisa kesesuaian antara perlakuan akuntansi dan Standar Akuntansi Keuangan serta Undang-undang Pajak. Analisa ini terutama ditekankan pada bagaimana perlakuan akuntansi atas metode pengakuan Pendapatan dan Biaya, serta bagaimana perlakuan Pajak Penghasilan Pasal 4 ayat 2 didalam pencatatan laporan Keuangan Proyek RS Santo Borromeus Gedung Elizabeth PT Adhi Karya (Persero) Tbk.

\section{HASIL DAN PEMBAHASAN}

\section{Hasil Penelitian}

Dalam dunia jasa konstruksi dikenal dengan dokumen konstruksi yaitu seluruh dokumen yang berlaku dan mengikat selama proses konstruksi berlangsung termasuk di antaranya dokumen tender dan dokumen kontrak. Kontraktor harus mempelajari dan menguasai dokumen tender agar dapat memenangkan proyek dan mendapatkan kontrak pekerjaan sebelum kemudian bekerja mewujudkan dokumen kontrak menjadi fisik bangunan. Kegiatan pertama yang dilakukan kontraktor demi memenangkan dan mendapatkan proyek menyiapkan kegiatan proses tender. Kontraktor harus menetapkan tim tender, menyiapkan data sumber daya manusia, identifikasi dokumen, tabel ketelusuran, survey, analisa resiko, analisa harga pasar, analisa harga 
pekerjaan, metode kerja, rencana anggaran proyek, princing strategi, rencana anggaran biaya, surat penawan, dokumen pendukung serta menyediakan SKN, jaminan pemeliharaan, rencana cash flow.

Setelah kegiatan proses tender dilakukan oleh kontraktor maka diumumkanlah pemenang proyek diikat dalam sebuah kontrak antara pemberi kerja (owner) dan penerima kerja (kontraktor). Di dalam kontrak kerja tertuang pasal pembayaran dan sistem pembayaran bagi si penerima kerja. Di sinilah kontraktor menerima pendapatannya. Berdasarkan Surat Perintah Mulai Kerja No. 003/PPSB/SPK/VI/2013 dimana tercantum Surat Penetapan Pemenang Tender dari Tim pembangunan Elizabeth Building Nomor 201/TP-EB/V/2013 tertanggal 23 mei 2013 berdasarkan Risalah Klarifikasi dan Negoisasi Pekerjaan Paket 2 tanggal 21 Mei 2013 dan dokumen-dokumen tender dan proses pemilihan nominated sub contractor (NC) untuk pekerjaan plafon dan partisi. Pekerjaan kusen, pintu dan jendela alumunium dan alumunium composit Panel (ACP), dan pekerjaan M-E-P yang tertuang dalam berita acara serah terima dokumen dan pelaksan Nominated Contractor ke Main Contractor (MC) paket 2 Tanggal 31 Mei 2013. Dalam Surat Perintah Mulai Kerja ini tercantum Nilai Kontrak Rp. 55.588.000.000, dan Addendum Kontrak 007/SPK-KER ADD/PPSB/V/2014 perpanjangan waktu pekerjaan selama 11 bulan, Jenis Kontrak Lump Sum Fix Price, dengan cara pembayaran Uang Muka 20\%, Jaminan Uang Pelaksanaan atau Retensi 5 $\%$ dari nilai kontrak diserahkan saat pengajuan uang muka, Waktu Pelaksanaan 9 bulan, masa pemeliharaan 180 hari atau 6 bulan sejak diterbitkan Berita Acara Serah Terima 1, terlampir tabel 1.

\section{Pengakuan Pendapatan dan Jurnal Pendapatan PT Adhi Karya (Persero) Tbk. Proyek RS Santo Borromeus Gedung Elizabeth}

Kebijakan pengakuan pendapatan jasa konstruksi PT Adhi karya (Persero) Tbk diakui dengan menggunakan metode persentase penyelesaian, dengan aturan sebagai berikut : a). Pendapatan yang dapat diestimasi Pendapatan didasarkan kepada volume hasil pelaksanaan setiap jenis pekerjaan terimbang dengan bobot pekerjaan yang diterapkan dalam kontrak. b). Pendapatan yang belum dapat diestimasi. Pendapatan didasarkan atas biaya yang telah dikeluarkan untuk pelaksanaan pekerjaaan tersebut. Jika kontrak telah ada dapat dilakukan penyesuaian pendapatan. Pengakuan pendapatan usaha ini harus didasarkan pada progres yang telah disetujui pemberi kerja pada setiap akhir periode pelaporan. Dalam studi kasus yang Peneliti lakukan pada PT Adhi Karya (Persero) Tbk Proyek RS Santo Borromeus pendapatan diterima adalah pembayaran uang muka $20 \%$, pembayaran progres pekerjaan dan pembayaran retensi $5 \%$. Adapun pencatatan akuntansi sebagai berikut :

\section{a). Pada saat pencairan uang muka maka cara menjurnal adalah akun bank disebelah debet dan akun hutang uang muka disebelah kredit.}

Transaksi : perusahaan menerima uang muka sebesar 20\% dari nilai kontrak exclude PPN : $20 \%$ dikali Rp. 50.534.545.455 (Excl. Ppn) sama dengan Rp. 10.106.909.091. Summary Pengakuan Pendapatan Proyek RS Santo Borromeus Gedung Elizabeth PT Ahi Karya (Persero) Tbk terlampir pada tabel 2

Pencatatan Jurnal Penerimaan
Include PPN $\frac{\text { :Tanggal 17 Juli 2013 }}{\text { Bank }}$


ISSN : $2406-7415$

e-ISSN : $2655-9919$

JURNAL AKUNTANSI DAN BISNIS KRISNADWIPAYANA

DOI: http://dx.doi.org/10.35137/jabk.v7i3.448

Vol. 7 No. 3 (September - Desember) 2020

Hutang Uang MukaRp. 9.803.701.818

PPN Keluaran Rp. 1.010.690.909

Pencatatan Jurnal PPh Pasal 4 ayat 2 sebesar 3\% adalah : Tanggal 10 Desember 2013

PPh Pasal 4 ayat 2 Rp. $\quad 303.207 .273$

Hutang Uang Muka Rp. 303.207.273

b). Pencatatan terhadap penerimaan termin sesuai progress dilapangan adalah sebesar persentase penyelesaian proyek yang dikaitkan dengan nilai kontrak yang sudah disepakati.

1. Termin 1 dengan persentese pekerjaan 6,56\%. Progress di lapangan 6,56\%. dikali nilai kontrak Rp. 50.534.545.455 sama dengan nilai progres Rp. 3.313.044.800 dikurangi potongan uang muka

$(20 \%$ X Rp. 3.313.044.800 = Rp. 662.608.960) dan potongan retensi (5\% X Rp. 3.313.044.800 = Rp. 165.652.240).

Pencatatan Jurnal Pendapatan : Tanggal 26 Agustus 2013
Piutang Prestasi Rp. 3.313.044.800
Sales Rp. 3.313.044.800

Pencatatan jurnal piutang : $\underline{\text { Tanggal } 20}$

September 2013

$\begin{array}{cc}\text { Piutang usaha Rp. } & 2.733 .261 .960 \\ \text { Potongan Uang mukaRp. } & 662.608 .960 \\ \text { Potongan retensi Rp. } & 165.652 .240 \\ \text { Piutang Prestasi } & \text { Rp. } 3.313 .044 .800 \\ \text { PPN Keluaran } & \text { Rp. } 248.478 .360\end{array}$

Pencatatan Jurnal Penerimaan Bank : Tanggal 11 Oktober 2013

\begin{tabular}{lll}
\hline Bank & \multicolumn{2}{c}{ Rp. 2.658 .718 .452} \\
& Piutang Usaha & Rp. 2.658 .718 .452
\end{tabular}

Pencatatan Jurnal PPh Pasal 4 ayat 2 :

Tanggal 10 Desember 2013

PPh Pasal 4 ayat 2 Rp. 74.543.508 $\begin{array}{ll}\text { Piutang Usaha } & \text { Rp. } 74.543 .508\end{array}$

2. Termin 2 dengan persentese pekerjaan kumulatif $17,871 \%$

Progress di lapangan saat ini $11,315 \%$. dikali nilai kontrak Rp. 50.534.545.455 sama dengan nilai progres Rp. 5.717.983.819 dikurangi potongan uang muka $(20 \%$ X 5.717.983.819 = Rp.
1.143.596.764) dan potongan retensi (5\% X 5.717.983.819= Rp. 285.899.191).

Pencatatan Jurnal Pendapatan : Tanggal 30 September 2013

Piutang Prestasi $\quad$ Rp. 5.717.983.819

$$
\text { Sales } \quad \text { Rp. 5.717.983.819 }
$$

Pencatatan jurnal piutang : Tanggal 18

Oktober 2013

$\begin{array}{ccc}\text { Piutang usaha } & \text { Rp. } 4.717 .336 .650 \\ \text { Potongan Uang muka } & \text { Rp. } & 1.143 .596 .764 \\ \text { Potongan retensi } & \text { Rp. } & 285.899 .191 \\ \text { Piutang Prestasi } & \text { Rp. } 5.717 .983 .819 \\ \text { PPN Keluaran } & \text { Rp. } \quad 428.848 .786\end{array}$

Pencatatan Jurnal Penerimaan Bank : Tanggal 1 Nopember 2013

\begin{tabular}{lll}
\hline Bank & \multicolumn{2}{c}{ Rp. 4.588 .682 .014} \\
& Piutang Usaha $\quad$ Rp. 4.588.682.014
\end{tabular}

Pencatatan Jurnal PPh Pasal 4 ayat 2 : Tanggal 14 Maret 2015

PPh Pasal 4 ayat 2 Rp. 128.654.636

Piutang Usaha Rp. 128.654 .636

3. Termin 3 dengan persentese pekerjaan kumulatif $27,95 \%$

Progres di lapangan saat ini 10,082\%. dikali nilai kontrak Rp. 50.534.545.455 sama dengan nilai progres Rp. 5.094.892.874 dikurangi potongan uang muka $(20 \% \mathrm{X}$ 5.094.892.874 = Rp. 1.018.978.575) dan potongan retensi $(5 \% \mathrm{X} 5.094 .892 .874=$ Rp. 254.744.644).

Pencatatan Jurnal Pendapatan : Tanggal 4 November 2013

$$
\begin{array}{cr}
\hline \text { Piutang Prestasi } & \text { Rp. } 5.094 .892 .874 \\
\text { Sales } & \text { Rp. 5.094.892.874 }
\end{array}
$$

Pencatatan jurnal piutang : Tanggal 20 Nopember 2013

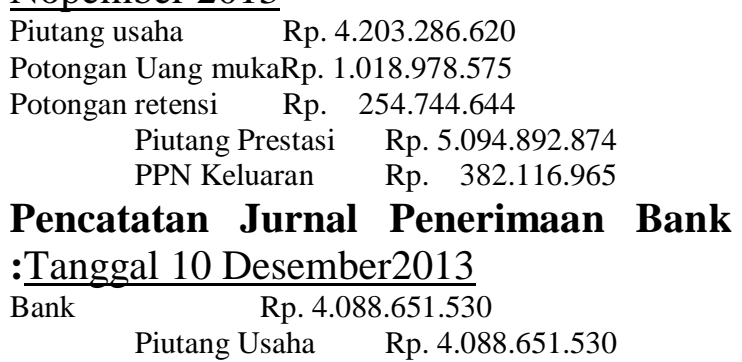

Pencatatan Jurnal PPh Pasal 4 ayat 2 : Tanggal 14 Maret 2014

PPh Pasal 4 ayat 2 Rp. 114.635.090 Piutang Usaha Rp. 114.635.090 
ISSN : $2406-7415$

e-ISSN : $2655-9919$

JURNAL AKUNTANSI DAN BISNIS KRISNADWIPAYANA DOI: http://dx.doi.org/10.35137/jabk.v7i3.448

Vol. 7 No. 3 (September - Desember) 2020

4. Termin 4 dengan persentese pekerjaan kumulatif $38,82 \%$

Progres di lapangan saat ini $10,862 \%$. dikali nilai kontrak Rp. 50.534.545.455 sama dengan nilai progres Rp. 5.489.062.326 dikurangi potongan uang muka $(20 \% \mathrm{X}$ 5.489.062.326 = Rp. 1.097.812.465) dan potongan retensi $(5 \% \mathrm{X} 5.489 .062 .326=$ Rp. 274.453.116).

Pencatatan Jurnal Pendapatan :Tanggal $\underline{02}$ Desember 2013

Piutang Prestasi $\quad$ Rp. 5.489.062.326 Sales $\quad$ Rp. 5.489.062.326

Pencatatan jurnal piutang : Tanggal 16

Desember 2013

Piutang usaha Rp. 4.528.476.420

Potongan Uang mukaRp. 1.097.812.465

Potongan retensi Rp. 274.453.116

Piutang Prestasi Rp. 5.489.062.326

PPN Keluaran Rp. 411.679.675

Pencatatan Jurnal Penerimaan Bank

:Tanggal 30 Desember 2013

Bank Rp. 4.404.972.518

Piutang Usaha Rp. 4.404.972.518

Pencatatan Jurnal PPh Pasal 4 ayat 2 :

Tanggal 14 Maret 2014

PPh Pasal 4 ayat 2 Rp. 123.503.902

$$
\text { Piutang Usaha Rp. 123.503.902 }
$$

5. Termin 5 dengan persentese pekerjaan kumulatif $48,87 \%$

Progres di lapangan saat ini $10,058 \%$. dikali nilai kontrak Rp. 50.534.545.455 sama dengan nilai progres Rp. 5.082.764.581 dikurangi potongan uang muka $(20 \% \mathrm{X}$ 5.082.764.581 = Rp. 1.016.552.916) dan potongan retensi $(5 \% \mathrm{X} 5.082 .764 .581=$ Rp. 254.138.229)

Pencatatan Jurnal Pendapatan : Tanggal 30 Desember 2013

$\begin{array}{cr}\text { Piutang Prsetasi } & \text { Rp. 5.082.764.581 } \\ \text { Sales } & \text { Rp. 5.082.764.581 }\end{array}$

Pencatatan jurnal piutang :Tanggal 20

Januari 2014

Piutang usaha Rp. 4.193.280.780

Potongan Uang mukaRp. 1.016.552.916

Potongan retensi Rp. 254.138.229

Piutang Prestasi $\quad$ Rp. 5.082.764.581

PPN Keluaran Rp. 381.207.344
Pencatatan Jurnal Penerimaan Bank : Tanggal 04 Februari 2014

\begin{tabular}{lll}
\hline Bank & \multicolumn{2}{c}{ Rp. 4.078 .918 .577} \\
& Piutang Usaha & Rp. 4.4078 .918 .577
\end{tabular}

Pencatatan Jurnal PPh Pasal 4 ayat 2 : Tanggal 13 Mei 2014

PPh Pasal 4 ayat 2 Rp. 114.362.203 Piutang Usaha Rp. 114.362.203

6. Termin 6 dengan persentese pekerjaan kumulatif $61,107 \%$

Progres di lapangan saat ini $12,235 \%$. dikali nilai kontrak Rp. 50.534.545.455 sama dengan nilai progres Rp. 6.182.901.636 dikurangi potongan uang muka $(20 \% \mathrm{X}$ 6.182.901.636 = Rp. 1.236.580.327 ) dan potongan retensi $(5 \% \mathrm{X} 6.182 .901 .636=$ Rp. 309.145.082 ).

Pencatatan Jurnal Pendapatan : Tanggal 3 Februari 2014

Piutang Prestasi Rp. 6.182.901.636 Sales Rp. 6.182.901.636

Pencatatan jurnal piutang : Tanggal 17 Februari 2014

Piutang usaha Rp. 5.100.893.850

Potongan Uang mukaRp. 1.236.580.327

Potongan retensi $\quad$ Rp. 309.145.082

Piutang Prestasi $\quad$ Rp. 6.182.901.636 PPN Keluaran Rp. 463.717.623

Pencatatan Jurnal Penerimaan Bank : Tanggal 06 Maret 2014

\begin{tabular}{lll}
\hline Bank & \multicolumn{2}{c}{ Rp. 4.961 .778 .563} \\
& Piutang Usaha & Rp. 4.961 .778 .563
\end{tabular}

Pencatatan Jurnal PPh Pasal 4 ayat 2 : Tanggal 13 Mei 2014

PPh Final 4 ayat 2 Rp. 139.115.287 $\begin{array}{ll}\text { Piutang Usaha } & \text { Rp. 139.115.287 }\end{array}$

7. Termin 7 dengan persentese pekerjaan kumulatif $66,34 \%$

Progres di lapangan saat ini 5,230\%. dikali nilai kontrak Rp. 50.534.545.455 sama dengan nilai progres Rp. 2.642.956.726 dikurangi potongan uang muka $(20 \% \mathrm{X}$ 2.642.956.726 = Rp. 528.591.345) dan potongan retensi $(5 \% \mathrm{X} 2.642 .956 .726=$ Rp. 132.147.836 ).

Pencatatan Jurnal Pendapatan Tanggal 3 Maret 2014

$\overline{\text { Piutang Prestasi }} \quad$ Rp. 2.642.956.726

Sales $\quad$ Rp. 2.642 .956 .726 
JURNAL AKUNTANSI DAN BISNIS KRISNADWIPAYANA

DOI: http://dx.doi.org/10.35137/jabk.v7i3.448

Pencatatan jurnal piutang : Tanggal 20

Maret 2014

\begin{tabular}{|c|c|}
\hline \multirow{2}{*}{\multicolumn{2}{|c|}{$\begin{array}{ll}\text { Piutang usaha } & \text { Rp. } 2.180 .439 .300\end{array}$}} \\
\hline & 528.591 .345 \\
\hline Potongan retensi & 132.147 .836 \\
\hline Piutang Prestasi & Rp. 2.642.956.726 \\
\hline PPN Keluaran & Rp. 198.221 .755 \\
\hline
\end{tabular}

Pencatatan Jurnal Penerimaan Bank : Tanggal 15 April 2014

Bank Rp. 2.120.972.774

Piutang Usaha Rp. 2.120.972.774

Pencatatan Jurnal PPh Pasal 4 ayat 2 :

Tanggal 31 Agustus 2016

PPh Pasal 4 ayat 2 Rp. 59.466.526

$\begin{array}{ll}\text { Piutang Usaha } & \text { Rp. } 59.466 .526\end{array}$

8. Termin 8 dengan persentese pekerjaan kumulatif $76,495 \%$

Progres di lapangan saat ini $10,158 \%$. dikali nilai kontrak Rp. 50.534.545.455 sama dengan nilai progres Rp. 5.133.299.126 dikurangi potongan uang muka $(20 \% \mathrm{X}$ 5.133.299.126 = Rp. 1.026.659.825 ) dan potongan retensi $(5 \% \mathrm{X} 5.133 .299 .126=$ Rp. 256.664.956).

Pencatatan Jurnal Pendapatan : $\underline{\text { Tanggal }}$ 1 April 2014

Piutang Prestasi $\quad$ Rp. 5.133.299.126

Sales Rp. 5.133.299.126

Pencatatan jurnal piutang : Tanggal 16 April 2014

\begin{tabular}{|c|c|}
\hline \\
\hline \multicolumn{2}{|c|}{$\begin{array}{l}\text { Piutang usaha } \quad \text { Rp. 4.234.971.780 } \\
\text { Potongan Uang mukaRp. } 1.026 .659 .825\end{array}$} \\
\hline Potongan retensi & 256.664 .956 \\
\hline Piutang Prestasi & Rp. 5.133.299.126 \\
\hline PPN Keluaran & Rp. $\quad 384.997 .435$ \\
\hline
\end{tabular}

Pencatatan Jurnal Penerimaan Bank : Tanggal 05 Mei 2014

\begin{tabular}{lll}
\hline Bank & \multicolumn{2}{c}{ Rp. 4.119.472.550 } \\
& Piutang Usaha & Rp. 4.119 .472 .550
\end{tabular}

Pencatatan Jurnal PPh Pasal 4 ayat 2 :

Tanggal 31 Agustus 2014

PPh Pasal 4 ayat 2 Rp. 115.499.230 Piutang Usaha Rp. 115.499.230

9. Termin 9 dengan persentese pekerjaan kumulatif $87,11 \%$

Progress di lapangan saat ini $10,609 \%$. dikali nilai kontrak Rp. 50.534.545.455 sama dengan nilai progres Rp. 5.361.209.926 dikurangi potongan uang muka $(20 \%$ X 5.361.209.926 = Rp.
Vol. 7 No. 3 (September - Desember) 2020

1.072.241.985) dan potongan retensi (5\% X 5.361.209.926 = Rp. 268.060.496 ).

Pencatatan Jurnal Pendapatan : Tanggal 28 April 2014

Piutang Prestasi Rp. 5.361.209.926

$$
\text { Sales Rp. 5.361.209.926 }
$$

Pencatatan jurnal piutang : Tanggal 13

Mei 2014

Piutang usaha $\quad$ Rp. 4.422.998.190

Potongan Uang mukaRp. 1.072.241.985

Potongan retensi Rp. 268.060.496

Piutang Prestasi $\quad$ Rp. 5.361.209.926 PPN Keluaran Rp. 402.090 .745

Pencatatan Jurnal Penerimaan Bank :Tanggal 28 Mei 2014

Bank Rp. 4.302.370.967

Piutang Usaha Rp. 4.302.370.967

Pencatatan Jurnal PPh Pasal 4 ayat 2 :

Tanggal 14 Maret 2015

PPh Pasal 4 ayat 2 Rp. 120.627.223

$$
\text { Piutang Usaha Rp. 120.627.223 }
$$

10. Termin 10 dengan persentese pekerjaan kumulatif $89,276 \%$

Progres di lapangan saat ini 10,609\%. dikali nilai kontrak Rp. 50.534.545.455 sama dengan nilai progres Rp. 1.097.610.326 dikurangi potongan uang muka $(20 \% \mathrm{X}$ 1.097.610.326 = Rp. 219.522.065) dan potongan retensi $(5 \% \mathrm{X} 1.097 .610 .326=$ Rp. 54.880.516).

Pencatatan Jurnal Pendapatan : Tanggal 28 April 2014

$\begin{array}{cr}\begin{array}{c}\text { Piutang Prestasi } \\ \text { Sales }\end{array} & \text { Rp. } 1.097 .610 .326 \\ \text { Rp. } 1.097 .610 .326\end{array}$

Pencatatan jurnal piutang : Tanggal 20 Juni 2014

Piutang usaha Rp. 905.528 .520

Potongan Uang mukaRp. 219.522.065

Potongan retensi Rp. 54.880.516

Piutang Prestasi $\quad$ Rp. 1.097.610.326

PPN Keluaran Rp. 82.320 .775

Pencatatan Jurnal Penerimaan Bank : Tanggal 08 Juli 2014

\begin{tabular}{lll}
\hline Bank & \multicolumn{2}{c}{ Rp. 880.832 .288} \\
& Piutang Usaha & Rp. 880.832 .288
\end{tabular}

Pencatatan Jurnal PPh Pasal 4 ayat 2 :

Tanggal 30 Nopember 2014

PPh Final 4 ayat 2 Rp. 24.696 .232

Piutang Usaha Rp. 24.696.232

11. Termin 11 dengan persentese pekerjaan kumulatif $91,135 \%$ 
ISSN : $2406-7415$

e-ISSN : $2655-9919$

JURNAL AKUNTANSI DAN BISNIS KRISNADWIPAYANA DOI: http://dx.doi.org/10.35137/jabk.v7i3.448

Vol. 7 No. 3 (September - Desember) 2020

Progres di lapangan saat ini 1,859\%. dikali nilai kontrak Rp. 50.534.545.455 sama dengan nilai progres Rp. 939.437.200 dikurangi potongan uang muka $(20 \% \mathrm{X}$ 939.437.200 = Rp. 187.887.440 ) dan potongan retensi $(5 \%$ X 939.437.200 $=\mathrm{Rp}$. 46.971.860).

Pencatatan Jurnal Pendapatan : Tanggal 30 Juni 2014

Piutang Prestasi Rp. 939.437.200

$$
\text { Sales Rp. } 939.437 .200
$$

Pencatatan jurnal piutang : Tanggal 23 Juli 2014

$\begin{array}{cc}\text { Piutang usaha } & \text { Rp. } 775.035 .690 \\ \text { Potongan Uang mukaRp. } 187.887 .440 \\ \begin{array}{cc}\text { Potongan retensi } & \text { Rp. } 46.971 .860 \\ \text { Piutang Prestasi } & \text { Rp. } 939.437 .200 \\ \text { PPN Keluaran } & \text { Rp. } 70.457 .790\end{array}\end{array}$

Pencatatan Jurnal Penerimaan Bank: Tanggal 12 Agustus2014

Bank Rp. 753.898.353

Piutang Usaha Rp. 753.898.353

Pencatatan Jurnal PPh Pasal 4 ayat 2 :

Tanggal 30 Nopember 2014

PPh Pasal 4 ayat 2 Rp. 21.137.337

$\begin{array}{ll}\text { Piutang Usaha } & \text { Rp. 21.137.337 }\end{array}$

12. Termin 12 dengan persentese pekerjaan kumulatif 93,374\%

Progress di lapangan saat ini 2,239\%. dikali nilai kontrak Rp. 50.534.545.455 sama dengan nilai progres Rp. 1.131.468.474 dikurangi potongan uang muka $(20 \% \mathrm{X}$ 1.131.468.474 = Rp. 226.293.695 ) dan potongan retensi $(5 \% \mathrm{X} 1.131 .468 .474=$ Rp. 56.573.424 ).

Pencatatan Jurnal Pendapatan : Tanggal 21 Juli 2014

Piutang Prestasi $\quad$ Rp. 1.131.468.474

Sales Rp. 1.131.468.474

Pencatatan jurnal piutang : Tanggal 25

Agustus 2014

Piutang usaha Rp. 933.461 .490

Potongan Uang mukaRp. 226.293.695

Potongan retensi Rp. 56.573.424

Piutang Prestasi Rp. 1.131.468.474

PPN Keluaran Rp. 84.860.135

Pencatatan Jurnal Penerimaan Bank :

Tanggal 08 September 2014

Bank Rp. 908.003.449

Piutang Usaha Rp. 908.003 .449
Pencatatan Jurnal PPh Pasal 4 ayat 2 :

Tanggal 30 Nopember 2014

PPh Pasal 4 ayat 2 Rp. 25.458 .041

Piutang Usaha Rp.25.458.041

13. Termin 13 dengan persentese pekerjaan kumulatif $96,771 \%$

Progres di lapangan saat ini 3,397\%. dikali nilai kontrak Rp. 50.534.545.455 sama dengan nilai progres Rp. 1.716.658.509 dikurangi potongan uang muka $(20 \% \mathrm{X}$ 1.716.658.509 = Rp. 343.331.702 ) dan potongan retensi $(5 \% \mathrm{X} 1.716 .658 .509=$ Rp. 85.832.925).

Pancatatan Jurnal Pendapatan : $\underline{\text { Tanggal }}$ 13 Oktober 2014

Piutang Prestasi Rp. 1.716.658.509

$$
\text { Sales } \quad \text { Rp. 1.716.658.509 }
$$

Pencatatan jurnal piutang : Tanggal 23

Oktober 2014

$\begin{array}{ccc}\text { Piutang usaha } & \text { Rp. } 1.416 .243 .270 \\ \text { Potongan Uang mukaRp. } & 343.331 .702 \\ \text { Potongan retensi } & \text { Rp. } & 85.832 .925 \\ \text { Piutang Prestasi } & \text { Rp. } 1.716 .658 .509 \\ \text { PPN Keluaran } & \text { Rp. } \quad 128.749 .388\end{array}$

Pencatatan Jurnal Penerimaan Bank :Tanggal 30 Nopember 2014

Bank Rp. 1.377.593.454

Piutang Usaha Rp. 1.377.593.454

Pencatatan Jurnal PPh Pasal 4 ayat 2

:Tanggal 13 Februari 2015

PPh Pasal 4 ayat 2 R p. 38.624.816

Piutang Usaha Rp. 38.624.816

14. Termyn 14 dengan persentese pekerjaan kumulatif $98,038 \%$

Progress di lapangan saat ini 1,267\%. dikali nilai kontrak Rp. 50.534.545.455 sama dengan nilai progres Rp. 640.272.690 dikurangi potongan uang muka ( $20 \% \mathrm{X}$ $640.272 .690=$ Rp. 128.054.538) dan potongan retensi $(5 \%$ X $640.272 .690=\mathrm{Rp}$. 32.013.635).

Pencatatan Jurnal Pendapatan :Tanggal 24 November 2014

Piutang Prestasi $\quad$ Rp. 640.272 .690

$$
\text { Sales } \quad \text { Rp. } 640.272 .690
$$

Pencatatan jurnal piutang :Tanggal 13

Desember 2014

Piutang usaha Rp. 528.224.970

Potongan Uang mukaRp. 128.054.538

Potongan retensi Rp. 32.013.635 
JURNAL AKUNTANSI DAN BISNIS KRISNADWIPAYANA

DOI: http://dx.doi.org/10.35137/jabk.v7i3.448

$$
\begin{array}{ll}
\text { Piutang Prestasi } & \text { Rp. 640.272.690 } \\
\text { PPN Keluaran } & \text { Rp. 48.020.452 }
\end{array}
$$

Pencatatan Jurnal Penerimaan Bank :Tanggal 30 Desember 2014

$\begin{array}{lr}\text { Bank } & \text { Rp. 513.793.834 } \\ \text { Piutang Usaha } & \text { Rp. 513.793.834 }\end{array}$

Pencatatan Jurnal PPh Pasal 4 ayat 2

:Tanggal 13 Februari 2015

PPh Pasal 4 ayat 2 Rp. 14.406.136

$$
\begin{array}{ll}
\text { Piutang Usaha } & \text { Rp. 14.406.136 }
\end{array}
$$

15. Termin 15 dengan persentese pekerjaan kumulatif $100 \%$

Progres di lapangan saat ini $1,961 \%$. dikali nilai kontrak Rp. 50.534.545.455 sama dengan nilai progres Rp. 1.147.246.165 dikurangi potongan uang muka ( $20 \% \mathrm{X}$ 1.147.246.165 = Rp. 198.196.487) dan potongan retensi $(5 \% \mathrm{X} 1.147 .246 .165=$ Rp. 57.362.308 ).

Pencatatan Jurnal Pendapatan :Tanggal 6 April 2015

$\begin{array}{cc}\text { Piutang Prestasi } & \text { Rp. 1.147.246.165 } \\ \text { Sales } & \text { Rp. 1.147.246.165 }\end{array}$

Pencatatan jurnal piutang : Tanggal 21

Mei 2015

Piutang usaha $\quad$ Rp. 980.856 .107

Potongan Uang mukaRp. 198.196.487

Potongan retensi Rp. 57.362.308 Piutang Prestasi $\quad$ Rp. 1.147.246.165 PPN Keluaran $\quad$ Rp. 89.168.737

Pencatatan Jurnal Penerimaan Bank : Tanggal 15 Juni 2015

Bank Rp. 954.080.485

Piutang Usaha Rp. 954.080.485

Pencatatan Jurnal PPh Pasal 4 ayat 2 :

Tanggal 31 Agustus 2016

PPh Final 4 ayat 2 Rp. 22.297.105

Piutang Usaha Rp. 22.297.105

\section{Pengakuan Biaya PT Adhi Karya (Persero) Tbk Proyek RS Santo \\ Borromeus Gedung Elizabeth.}

Biaya-biaya yang termasuk dalam proyek RS Borromeus Gedung Elizabeth Bandung adalah sebagai berikut :

1. Biaya Real Cost

- Bahan

- Upah

- Sub Kontraktor (Sub Kontraktor Civil, Sub Kontraktor NC, Sub Kontraktor Interior/ Furnitur)
Vol. 7 No. 3 (September - Desember) 2020

- Provisional Sum (PS)

2. Alat, SPP, Dan Biaya Umum

- Biaya Alat

- Biaya SPP

- Biaya Umum

3. Biaya Asuransi

- Provisi atas jaminan Bank/ Asuransi

- Asuransi CAR

- Diductible

- Asuransi Personil Accident

- Asuransi Tenaga Kerja

4. Biaya Kenaikan Harga

- SKBDN Pembukaan

- SKBDN Perpanjangan

5. Biaya Cash Flow \& SKBDN

- Biaya Alat

- Biaya SPP

- Biaya Umum

- Fee Kordinasi

6. Biaya Main Contractor

7. Biaya Pemeliharaan

a. Laporan Biaya Proyek RS Santo Borromeus Gedung Elizabeth PT Adhi Karya (Persero) Tbk.

Summary Laporan Biaya PT Adhi Karya (Persero) Tbk. Proyek RS Borromeus Gd. Elisabeth terlampir pada tabel 3.

b. Jurnal Biaya Proyek RS Santo Borromeus Gedung Elizabeth PT Adhi Karya (Persero) Tbk.

Jurnal merupakan ringkasan dari banyak transaksi yang salurannya dicatat pada (satu periode akuntansi) untuk mencatat transaksi diatas adalah sebagai berikut :

2013 :

Biaya Usaha 16.225.014.421

Bank 16.225.014.421

2014 :

Biaya Usaha 28.410.270.327

Bank 28.410.270.327 
2015 :

$\begin{array}{cr}\text { Biaya Usaha } & 287.956 .818 \\ \text { Bank } & 287.956 .818\end{array}$

c. Rincian Biaya Proyek RS Santo Borromeus Gedung Elizabeth PT Adhi Karya (Persero) Tbk.

Summary Pengakuan Biaya PT Adhi

Karya (Persero) Tbk.Proyek RS

Borromeus Gd. Elisabeth Terlampir pada tabel 4.

d. Penyajian Biaya di Laporan

Keuangan Proyek RS Santo

Borromeus Gedung Elizabeth PT Adhi Karya (Persero) Tbk.

Laporan Laba Rugi Per Desember 2013, terlampir di Tabel 5.Laporan Laba Rugi Per Desember 2014 terlampir di Tabel 6.Laporan Laba Rugi Per Desember 2015 terlampir di Tabel 6. Sedangkan untuk Laporan Neraca Per Desember 2013 terlampir di Tabel 8. Laporan Neraca Per Desember 2014, terlampir di Tabel 9, Laporan Neraca Per Desember 2015, terlampir di Tabel 10

\section{Pengakuan Pajak Pajak}

Penghasilan Pasal 4 ayat 2 PT Adhi Karya (Persero) Tbk Proyek RS Santo Borromeus Gedung Elizabeth.

Summary Pengakuan PPh Pasal 4 ayat 2 PT Adhi Karya (Persero) Tbk. Proyek RS Borromeus Gd. Elizabeth terlampir di Tabel 11

Pengakuan pendapatan di Tahun 2013 menurut pencatatan senilai Rp. 25.544.701.333 sedangkan pencatatan aktual Rp. 25.911.519.961 dimana selisih tersebut adalah adanya penangguhan $\mathrm{PPh}$ pasal 4 ayat 2 yang belum dicatat karena pihak perusahaan belum mendapatkan bukti potong dari pihak Owner sebesar Rp. 366.818.628. Nilai ini dicatat ditahun 2014 mengakibatkan perbedaan waktu pengakuan pendapatan sebesar Rp. 366.818.628. Sehingga laba di tahun 2013 belum dikurangi PPh pasal 4 ayat 2 yang belum terima bukti potong.

Ditahun 2014 pendapatan di catat Rp. 24.017.634.809 sedangkan aktualnya $\mathrm{Rp}$. 24.128.144.748 selisihnya Rp. 110.509.939. selisih tersebut adalah $\mathrm{PPh}$ pasal 4 ayat 2 yang belum di akui karena belum terima bukti potong. Sedangkan di tahun 2015 pencatatan sudah sesuai karena tidak ada lagi pajak tangguhannya.

\section{Pengaruh Pendapatan dan Biaya Serta PPH Pasal 4 Ayat 2 Terhadap Laporan Keuangan PT Adhi Karya (Persero) Tbk Proyek RS Santo Borromeus Gedung Elizabeth.}

Secara konseptual dapat diukur jika memenuhi kualitas pengukuran dan keandalan maka kualitas tersebut harus dioperasikan dalam bentuk kriteria pengakuan pendapatan. Biaya merupakan konsep arus yang menggambarkan perubahan yang tidak menguntungkan sumber daya perusahaan. Biaya timbul akibat adanya aktivitas perusahaan yang biasanya terbentuk pada arus kas atau berkurangnya aset seperti kas dan setara kas. Biaya diakui dalam laporan Laba Rugi atas dasar pengeluaran tidak menghasilkan manfaat ekonomi masa depan atau jika tidak memenuhi syarat maka diakui dalam Neraca sebagai Aset. Pendapatan dan biaya sangat berpengaruh terhadap Laporan Keuangan karena semakin besar pendapatan maka semakin besar pula laba yang didapatkan dan sebaliknya jika biaya semakin besar maka Laba perusahaan akan semakin kecil.

Pajak Penghasilan Pasal 4 ayat 2 sebagai pengurang pendapatan karena dalam perusahaan konstruksi pemungut Pajak Penghasilan Pasal 4 ayat 2 adalah Owner. Dalam hal pencatatan perusahaan tidak dapat langsung mengakui Pajak Penghasilan Pasal 4 ayat 2 dikarenakan syarat mengakui Pajak Penghasilan 4 ayat 2 
jika owner sudah memberikan bukti potong kepada perusahaan yang akhirnya berdampak besarnya pendapatan di laporan Laba Rugi, karena masih ada pajak tangguhan yang belum dicatat.

\section{Hasil Analisis}

Menurut PSAK No.34 bahwa pengakuan pendapatan jasa konstruksi dinyatakan bahwa bila hasil (outcome) kontrak konstruksi dapat diestimasi secara andal, pendapatan kontrak yang berhubungan dengan kontrak konstruksi harus diakui sebagai pendapatan dengan memperhatikan tahap penyelesaian aktivitas kontrak pada tanggal neraca. Pada prakteknya PT Adhi Karya (Persero) Tbk menetapkan pengakuan pendapatan kontrak jangka panjang dengan menggunakan Metode Persentase Penyelesaian. Setiap akhir periode dilakukan perhitungan laba atau rugi berdasarkan persentase penyelesaian. Taksiran Laba dicatat dengan mendebit pengakuan laba kontrak jangka panjang. Metode pembukuan akuntansi atas dasar akrual (accrual basic) yaitu pendapatan dicatat atau dibukukan pada saat terjadinya transaksi yang bersangkutan. Metode pengakuan atas pendapatan jasa konstruksi adalah berdasarkan proyek dilapangan digunakan dengan taksiran engineer dengan menghitung volume pekerjaan yang telah diselesaikan dan dituangkan dalam laporan prestasi proyek sebagai dasar pencatatan pendapatan jasa konstruksi.

Dalam penyelesaian proyek memakan waktu 3 periode akuntansi. Penentuan atau penyajian laporan keuangan dalam hal laporan laba rugi perusahaan menggunakan metode persentase penyelesaian, dimana PT Adhi Karya (Persero) Tbk diakui pada saat selesainya bangunan atau suatu proyek.

\section{KESIMPULAN DAN SARAN}

\section{Kesimpulan}

Berdasarkan hasil analisis dan pembahasan diatas, maka ditarik kesimpulan prosedur pencatatan akuntansi pendapatan dan biaya yang digunakan dalam pembiayaan proyek menggunakan metode persentase penyelesaian (Precentage of completion method). Dalam metode ini semua biaya yang dikeluarkan untuk pembangunan dicatat dalam rekening proyek dalam pelaksanaan. Setiap akhir periode dilakukan perhitungan Laba atau Rugi berdasarkan persentase penyelesaian. Pencatatan Pajak Penghasilan Pasal 4 ayat 2 dapat diakui sebagai pengurang pendapatan setelah perusahaan menerima bukti potong dari owner.

\section{Saran}

Setelah ditarik kesimpulan berdasarkan analisis Peneliti tersebut diatas, maka Peneliti mencoba memberikan saran-saran dan semoga saran tersebut bermanfaat bagi perusahaan yang bersangkutan pengakuan prestasi pekerjaan sebaiknya dilakukan sesuai dengan biayabiaya yang dikeluarkan berdasarkan yang telah dicatat di kartu pembebanan dan untuk pengakuan Pajak Penghasilan Pasal 4 Ayat 2 harus dicatat secara andal

\section{DAFTAR PUSTAKA}

Joel D. Wisner, Keah-Choon Tan, G. Keong Leong. (2008). Principles Of Supply Chain Management. SouthWestern Cengage Learning.

Nelson Lam, Peter Lau. (2012). Akuntansi Keuangan. Edisi 2 Buku 2. Salemba Empat.

Waluyo. (2012). Akuntansi Pajak. Edisi 6. Salemba Empat. 
ISSN : $2406-7415$

e-ISSN : $2655-9919$

JURNAL AKUNTANSI DAN BISNIS KRISNADWIPAYANA

DOI: http://dx.doi.org/10.35137/jabk.v7i3.448

Vol. 7 No. 3 (September - Desember) 2020

Sugiono. (2013). Metode Penelitian Kuantatif, Kualitatif dan $R \& D$. Bandung: Alfabeta.

Mulyadi. (2016). Sistem Akuntansi. Edisi Ke 4. Jakarta: Salemba Empat.

Siti, Resmi. (2014). Perpajakan Teori dan Kasus. Edisi Ke 7. Jakarta: Salemba Empat.

Ikatan Akuntan Indonesia. (2012). Standar Akuntansi Keuangan. Jakarta: Salemba Empat.

Kieso, D. E, Jerry J. Weygandt, J. J \& Warfiels, T. D. (2011). Intermediete Accounting, Emil Salim, Jilid 1. Edisi 10. Jakarta: Erlangga.

Rantunuman. (2013). Analisis Pengakuan Pendapatan dan Persentase Penyelesaian Dalam Penyajian Laporan Keuangan.

Rezwan.

Rizki.

Blogspot.com/2013/05/Akuntansi

Kontrak Konstruksi.html 
ISSN : $2406-7415$

e-ISSN : $2655-9919$

JURNAL AKUNTANSI DAN BISNIS KRISNADWIPAYANA DOI: http://dx.doi.org/10.35137/jabk.v7i3.448

Vol. 7 No. 3 (September - Desember) 2020

\section{LAMPIRAN}

Tabel 1.Summary RAB (Rencana Anggaran Biaya) PT Adhi Karya (Persero) Tbk. Proyek RS Borromeus Gd. Elizabeth Bandung

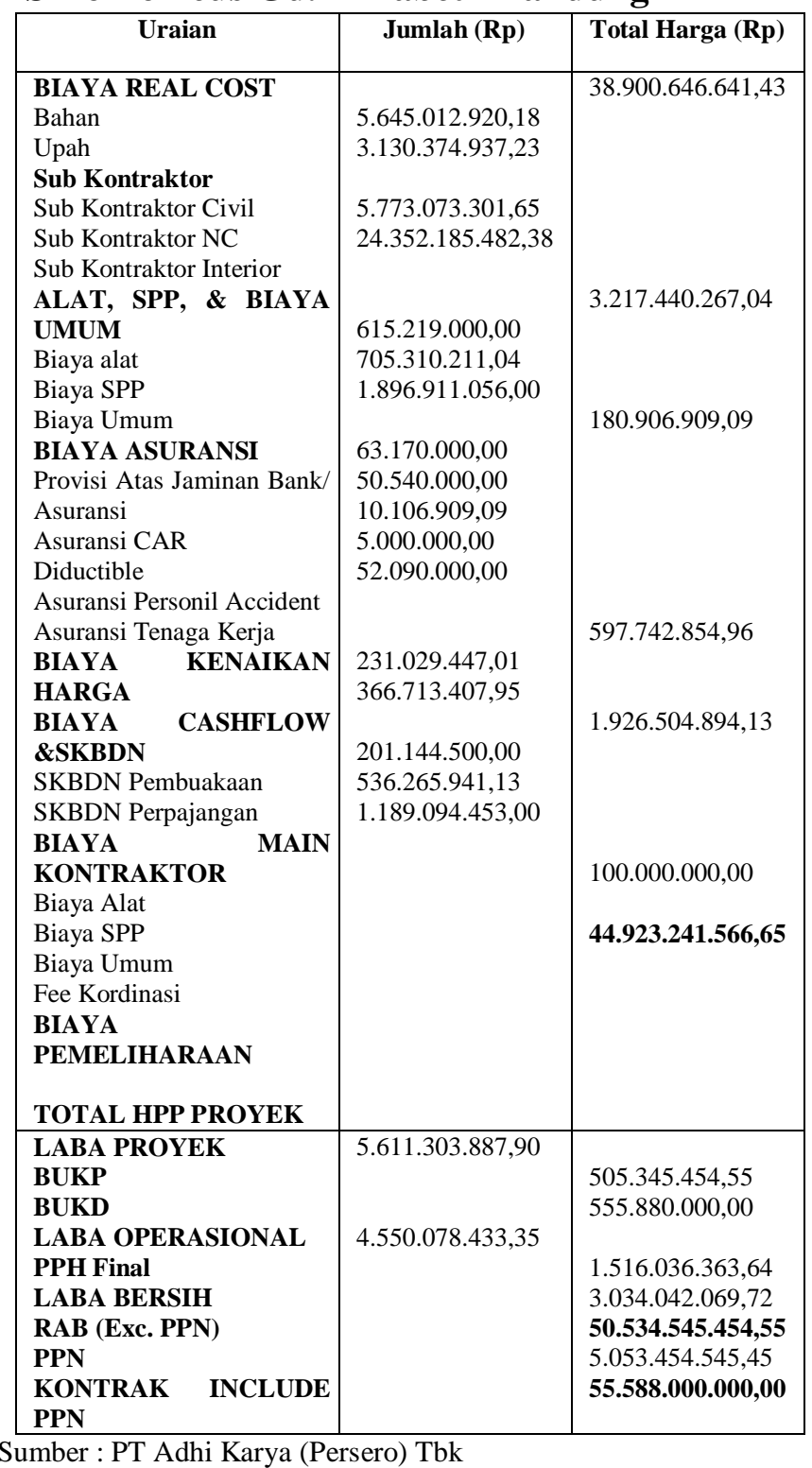

Tabel 2. Summary Pengakuan Pendapatan Proyek RS Santo Borromeus Gedung Elizabeth PT Ahi Karya (Persero) Tbk.

\begin{tabular}{|c|c|c|c|c|c|}
\hline $\begin{array}{l}\text { TERM } \\
\text { YN }\end{array}$ & $\begin{array}{c}\text { TG } \\
\text { L }\end{array}$ & $\begin{array}{c}\text { PROGR } \\
\text { ESS } \\
\text { PENGA } \\
\text { WAS }\end{array}$ & $\begin{array}{c}\text { TG } \\
\text { L }\end{array}$ & $\begin{array}{l}\text { UANG } \\
\text { MUKA }\end{array}$ & $\begin{array}{c}\text { PENDAPA } \\
\text { TAN }\end{array}$ \\
\hline
\end{tabular}

\begin{tabular}{|c|c|c|c|c|c|}
\hline $\begin{array}{l}\text { Uang } \\
\text { Muka }\end{array}$ & & & $\begin{array}{l}27 \\
\text { Jun } \\
13 \\
\end{array}$ & $\begin{array}{r}10.106 .909 \\
.091\end{array}$ & \\
\hline 1 & $\begin{array}{l}26 \\
\mathrm{Ag} \\
\mathrm{st} \\
13\end{array}$ & $6,556 \%$ & $\begin{array}{l}20 \\
\text { Sep } \\
13\end{array}$ & & $\begin{array}{r}3.313 .044 .8 \\
00\end{array}$ \\
\hline 2 & $\begin{array}{l}30 \\
\text { Sep } \\
13\end{array}$ & $11,315 \%$ & $\begin{array}{l}17 \\
\text { Okt } \\
13 \\
\end{array}$ & & $\begin{array}{r}5.717 .983 .8 \\
19\end{array}$ \\
\hline 3 & $\begin{array}{l}04 \\
\text { No } \\
\mathrm{v} \\
13 \\
\end{array}$ & $10,082 \%$ & $\begin{array}{l}18 \\
\text { No } \\
\mathrm{v} \\
13 \\
\end{array}$ & & $\begin{array}{r}5.094 .892 .8 \\
74\end{array}$ \\
\hline 4 & $\begin{array}{l}25 \\
\text { No } \\
\mathrm{v} \\
13 \\
\end{array}$ & $10,862 \%$ & $\begin{array}{l}14 \\
\text { De } \\
\mathrm{c} \\
13 \\
\end{array}$ & & $\begin{array}{r}5.489 .062 .3 \\
27\end{array}$ \\
\hline 5 & $\begin{array}{l}30 \\
\text { Des } \\
13 \\
\end{array}$ & $10,058 \%$ & $\begin{array}{l}20 \\
\text { Jan } \\
14\end{array}$ & & $\begin{array}{r}5.082 .764 .5 \\
81\end{array}$ \\
\hline 6 & $\begin{array}{l}03 \\
\text { Feb } \\
14\end{array}$ & $12,235 \%$ & $\begin{array}{l}19 \\
\text { Feb } \\
14\end{array}$ & & $\begin{array}{r}6.182 .901 .6 \\
36\end{array}$ \\
\hline 7 & $\begin{array}{l}03 \\
\mathrm{Ma} \\
\mathrm{r} \\
14\end{array}$ & $5,230 \%$ & $\begin{array}{l}20 \\
\mathrm{Ma} \\
\mathrm{r} \\
14 \\
\end{array}$ & & $\begin{array}{r}2.642 .956 .7 \\
26\end{array}$ \\
\hline 8 & $\begin{array}{l}25 \\
\mathrm{Ma} \\
\mathrm{r} \\
14 \\
\end{array}$ & $10,158 \%$ & $\begin{array}{l}15 \\
\text { Apr } \\
14\end{array}$ & & $\begin{array}{r}5.133 .299 .1 \\
26\end{array}$ \\
\hline 9 & $\begin{array}{l}28 \\
\mathrm{Apr} \\
14\end{array}$ & $10,609 \%$ & $\begin{array}{l}13 \\
\mathrm{Me} \\
\mathrm{i} 14\end{array}$ & & $\begin{array}{r}5.361 .209 .9 \\
26\end{array}$ \\
\hline 10 & $\begin{array}{l}02 \\
\text { Jun } \\
14 \\
\end{array}$ & $2,172 \%$ & $\begin{array}{l}17 \\
\text { Jun } \\
14\end{array}$ & & $\begin{array}{r}1.097 .610 .3 \\
26\end{array}$ \\
\hline 11 & $\begin{array}{l}30 \\
\text { Jun } \\
14\end{array}$ & $1,859 \%$ & $\begin{array}{l}21 \\
\text { Jul } \\
14\end{array}$ & & 939.437 .200 \\
\hline 12 & $\begin{array}{l}21 \\
\text { Jul } \\
14\end{array}$ & $2,239 \%$ & $\begin{array}{l}23 \\
\mathrm{Ag} \\
\mathrm{s} \\
14\end{array}$ & & $\begin{array}{r}1.131 .468 .4 \\
74\end{array}$ \\
\hline 13 & $\begin{array}{l}13 \\
\text { Okt } \\
14\end{array}$ & $3,397 \%$ & $\begin{array}{l}22 \\
\text { Oct } \\
14\end{array}$ & & $\begin{array}{r}1.716 .658 .5 \\
09\end{array}$ \\
\hline 14 & $\begin{array}{l}24 \\
\text { No } \\
\mathrm{v} \\
14\end{array}$ & $1,267 \%$ & $\begin{array}{l}13 \\
\mathrm{De} \\
\mathrm{c} \\
14 \\
\end{array}$ & & 640.272 .690 \\
\hline 15 & $\begin{array}{l}24 \\
\text { Apr } \\
15\end{array}$ & $1,961 \%$ & $\begin{array}{l}21 \\
\mathrm{Me} \\
\text { i } 15\end{array}$ & & $\begin{array}{r}1.147 .246 .1 \\
65\end{array}$ \\
\hline $\begin{array}{c}\text { TOTA } \\
\text { L }\end{array}$ & & $100 \%$ & & & $\begin{array}{r}50.534 .545 \\
455\end{array}$ \\
\hline
\end{tabular}

Sumber: PT Adhi Karya (Persero) Tbk.

Tabel 3. Summary Laporan Biaya PT Adhi Karya (Persero) Tbk. Proyek RS Borromeus Gd. Elisabeth

\begin{tabular}{|c|c|c|}
\hline Tahun & $\begin{array}{c}\text { Sesuai Real } \\
\text { Biaya Proyek }\end{array}$ & $\begin{array}{c}\text { Sesuai Laporan } \\
\text { Pengawas }\end{array}$ \\
\hline $\mathbf{2 0 1 3}$ & 16.225 .014 .421 & 16.225 .014 .421 \\
\hline $\mathbf{2 0 1 4}$ & 28.410 .270 .327 & 28.410 .270 .327 \\
\hline $\mathbf{2 0 1 5}$ & 287.956 .818 & 287.956 .818 \\
\hline
\end{tabular}


ISSN : $2406-7415$

e-ISSN : $2655-9919$

JURNAL AKUNTANSI DAN BISNIS KRISNADWIPAYANA

DOI: http://dx.doi.org/10.35137/jabk.v7i3.448

Vol. 7 No. 3 (September - Desember) 2020

\begin{tabular}{|l|l|l|}
\hline & 44.923.241.566 & 44.923.241.566 \\
\hline
\end{tabular}

Tabel 4.Summary Pengakuan Biaya PT Adhi Karya (Persero) Tbk.Proyek RS Borromeus Gd. Elisabeth

\begin{tabular}{|c|c|c|c|c|c|c|}
\hline $\begin{array}{c}\text { Ur } \\
\text { aia } \\
\mathbf{n}\end{array}$ & Upah & Bahan & $\begin{array}{l}\text { Sub. } \\
\text { Kontr } \\
\text { aktor }\end{array}$ & $\begin{array}{c}\text { Perala } \\
\tan \end{array}$ & $\begin{array}{c}\mathbf{U m u} \\
\mathbf{m}\end{array}$ & $\underset{\mathbf{h}}{\text { Jumla }}$ \\
\hline $\begin{array}{c}\text { Bia } \\
\text { ya }\end{array}$ & $\begin{array}{c}1.153 . \\
732.96\end{array}$ & $\begin{array}{r}1.592 . \\
90130\end{array}$ & $\begin{array}{r}10.724 \\
479.33\end{array}$ & $\begin{array}{l}1.391 . \\
3704\end{array}$ & $\begin{array}{l}1.391 . \\
37042\end{array}$ & 16.225 . \\
\hline $\begin{array}{l}20 \\
13\end{array}$ & 3 & 9 & 8 & 4 & 4 & 1 \\
\hline $\begin{array}{c}\text { Bia } \\
\text { ya }\end{array}$ & $\begin{array}{r}1.939 . \\
712.90\end{array}$ & $\begin{array}{r}3.968 . \\
980.51\end{array}$ & $\begin{array}{r}19.232 \\
882.80\end{array}$ & $\begin{array}{r}666.56 \\
9.228\end{array}$ & $\begin{array}{r}666.56 \\
9.228\end{array}$ & $\begin{array}{r}28.410 \\
270.32\end{array}$ \\
\hline $\begin{array}{l}20 \\
14\end{array}$ & 0 & 1 & 2 & & & 7 \\
\hline Bia & 36.929 & 83.131 & 167.89 & - & - & 287.95 \\
\hline $\begin{array}{l}\text { ya } \\
20 \\
15\end{array}$ & .074 & . 100 & 6.644 & & & 6.818 \\
\hline $\begin{array}{l}\text { To } \\
\text { tal }\end{array}$ & $\begin{array}{r}3.130 . \\
374.93\end{array}$ & $\begin{array}{r}5.645 . \\
012.92\end{array}$ & $\begin{array}{r}30.125 \\
258.78\end{array}$ & $\begin{array}{r}2.057 \\
939.65\end{array}$ & $\begin{array}{r}3.964 . \\
655.27\end{array}$ & $\begin{array}{r}44.923 . \\
241.56\end{array}$ \\
\hline $\begin{array}{c}\text { Bia } \\
\text { ya }\end{array}$ & 7 & 0 & 4 & 2 & 3 & 6 \\
\hline
\end{tabular}

Tabel 5. Laporan Laba Rugi Per Desember 2013

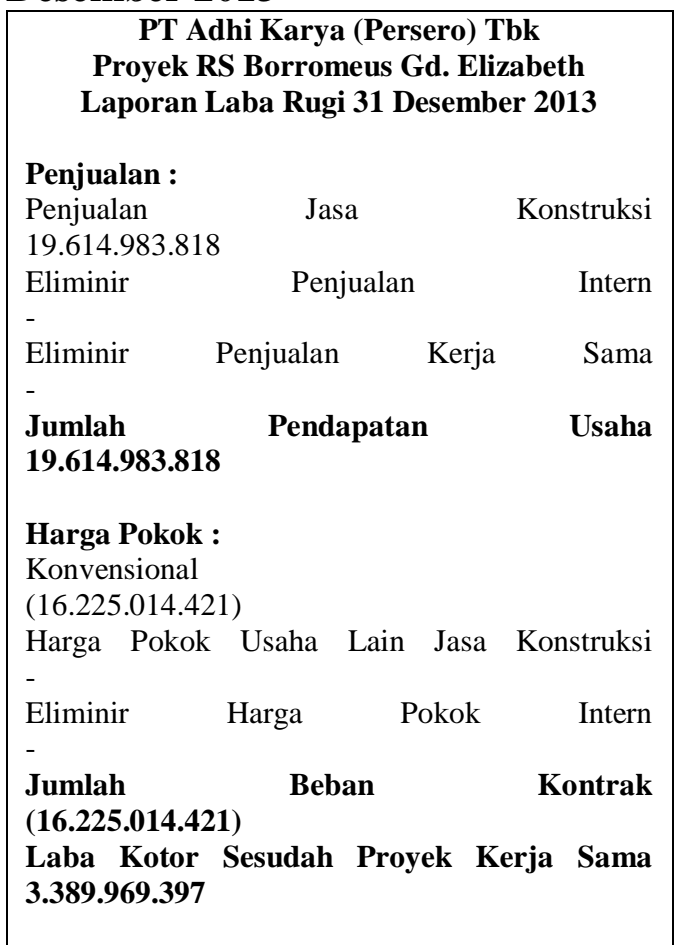

\begin{tabular}{|c|c|c|}
\hline \multicolumn{3}{|l|}{ Beban Usaha : } \\
\hline Beban Um & lum dan & Administrasi \\
\hline Biaya & & Pengembangan \\
\hline Beban & & Pemasaran \\
\hline Laba & (Rugi) & Usaha \\
\hline $\begin{array}{l}\text { Laba (Rugi) } \\
\text { 3.389.969.397 }\end{array}$ & Sebelum Pajak & Penghasilan \\
\hline $\begin{array}{l}\text { Pendapatan }(\mathbf{B e} \\
\text { Beban }\end{array}$ & ban) Non Operas & ional \\
\hline Pendapatan & & Bunga \\
\hline $\begin{array}{l}\text { Pendapatan } \\
911.807\end{array}$ & & Lain-lain \\
\hline $\begin{array}{l}\text { Laba } \\
(783.046)\end{array}$ & (Rugi) & Usaha \\
\hline $\begin{array}{l}\text { Laba (Rugi) } \\
\text { 3.389.186.351 }\end{array}$ & Sebelum Pajak & Penghasilan \\
\hline Pajak Penghasi & $\operatorname{lan}$ & \\
\hline $\begin{array}{l}\text { Pajak } \\
-\end{array}$ & Penghasilan & Badan \\
\hline $\begin{array}{l}\text { Pajak } \\
(377.750 .780)\end{array}$ & Penghasilan & Final \\
\hline $\begin{array}{l}\mathrm{PPh} \\
-\end{array}$ & & Tangguhan \\
\hline $\begin{array}{l}\text { Jumlah } \\
(377.750 .780)\end{array}$ & Pajak & Penghasilan \\
\hline $\begin{array}{l}\text { LABA } \\
\text { 3.011.435.571 }\end{array}$ & (RUGI) & BERSIH \\
\hline
\end{tabular}

Copyright (c) 2020 Herry Winarto, Iwan Ardiawan 
ISSN : $2406-7415$

e-ISSN : $2655-9919$

JURNAL AKUNTANSI DAN BISNIS KRISNADWIPAYANA

DOI: http://dx.doi.org/10.35137/jabk.v7i3.448

Vol. 7 No. 3 (September - Desember) 2020

Tabel 6. Laporan Laba Rugi Per

Desember 2014

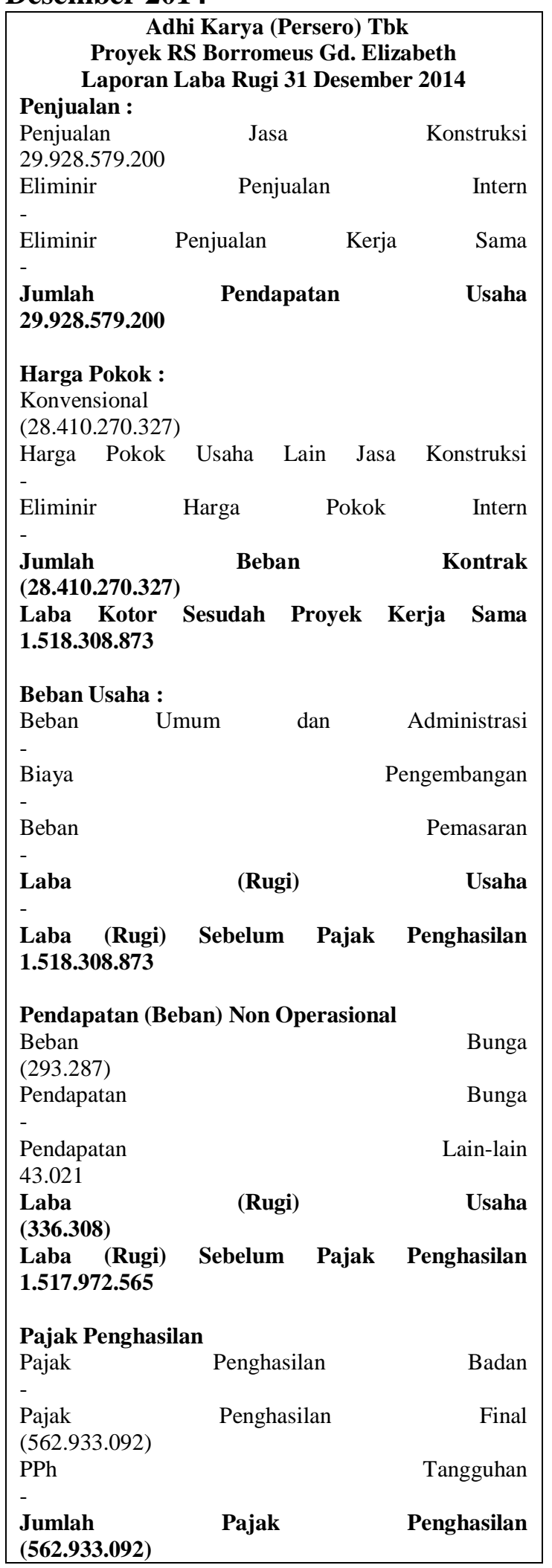

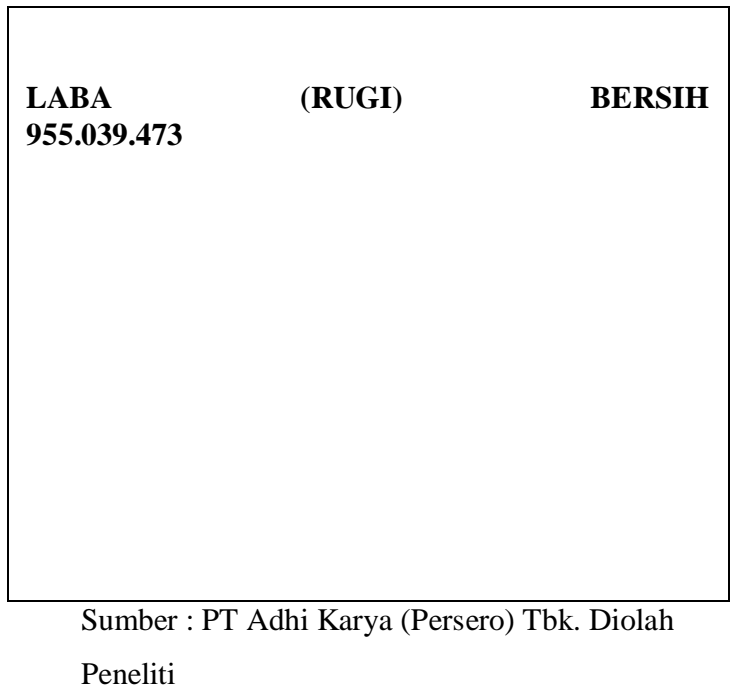

Tabel 7. Laporan Laba Rugi Per Desember 2015

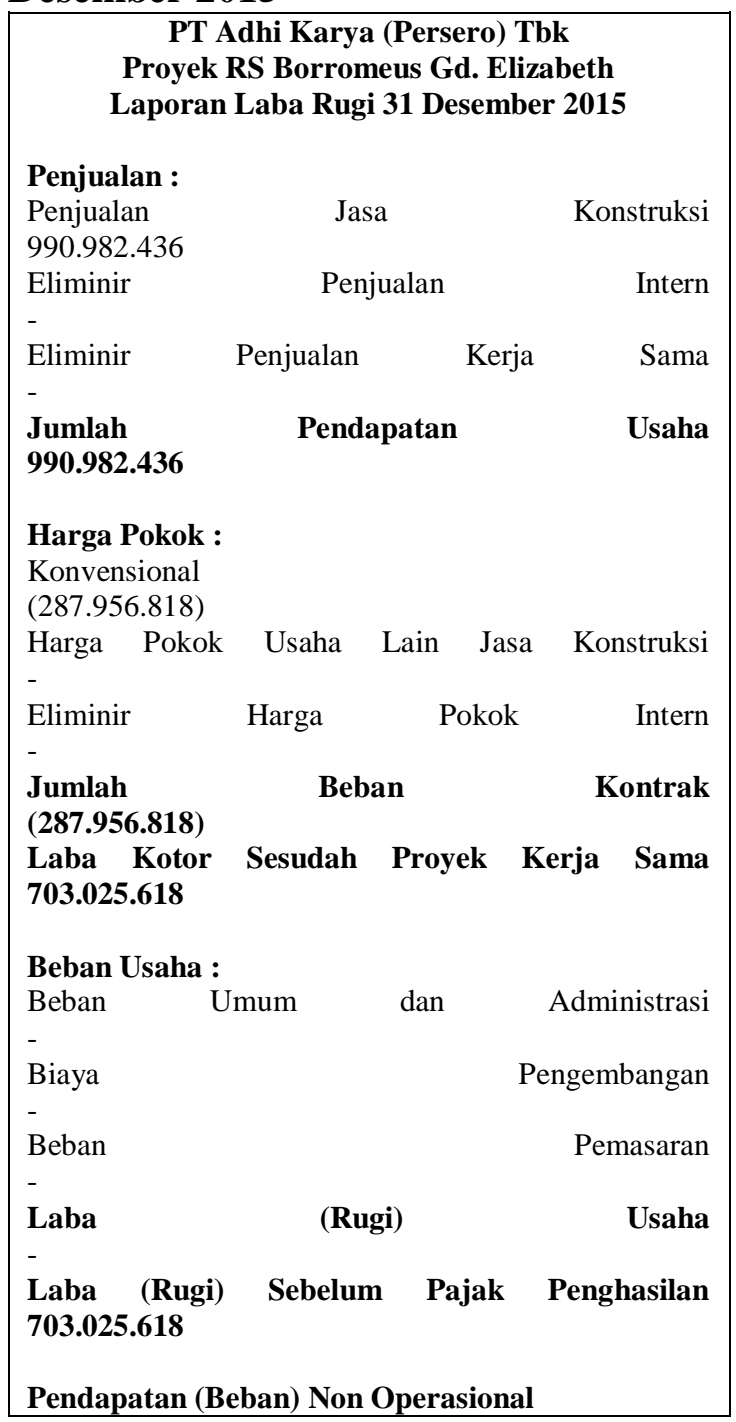


ISSN : $2406-7415$

e-ISSN : $2655-9919$

JURNAL AKUNTANSI DAN BISNIS KRISNADWIPAYANA DOI: http://dx.doi.org/10.35137/jabk.v7i3.448

Vol. 7 No. 3 (September - Desember) 2020

\begin{tabular}{|c|c|c|}
\hline \multicolumn{2}{|l|}{$\begin{array}{l}\text { Beban } \\
(183.604)\end{array}$} & Bunga \\
\hline \multicolumn{2}{|l|}{$\begin{array}{l}\text { Pendapatan } \\
\text { - }\end{array}$} & Bunga \\
\hline \multicolumn{2}{|l|}{$\begin{array}{l}\text { Pendapatan } \\
264.166\end{array}$} & Lain-lain \\
\hline \multirow{2}{*}{$\begin{array}{l}\text { 80.562 } \\
\text { Laba (Rugi) } \\
\text { 703.106.180 }\end{array}$} & (Rugi) & Usaha \\
\hline & Sebelum Pajak & Penghasilan \\
\hline \multicolumn{3}{|c|}{ Pajak Penghasilan } \\
\hline Pajak & Penghasilan & Badan \\
\hline $\begin{array}{l}\text { Pajak } \\
(504.104 .189)\end{array}$ & Penghasilan & Final \\
\hline $\begin{array}{l}\mathrm{PPh} \\
-\end{array}$ & & Tangguhan \\
\hline $\begin{array}{l}\text { Jumlah } \\
(504.104 .189)\end{array}$ & Pajak & Penghasilan \\
\hline $\begin{array}{l}\text { LABA } \\
199.001 .991\end{array}$ & (RUGI) & BERSIH \\
\hline
\end{tabular}

Tabel 8. Laporan Neraca Per Desember 2013

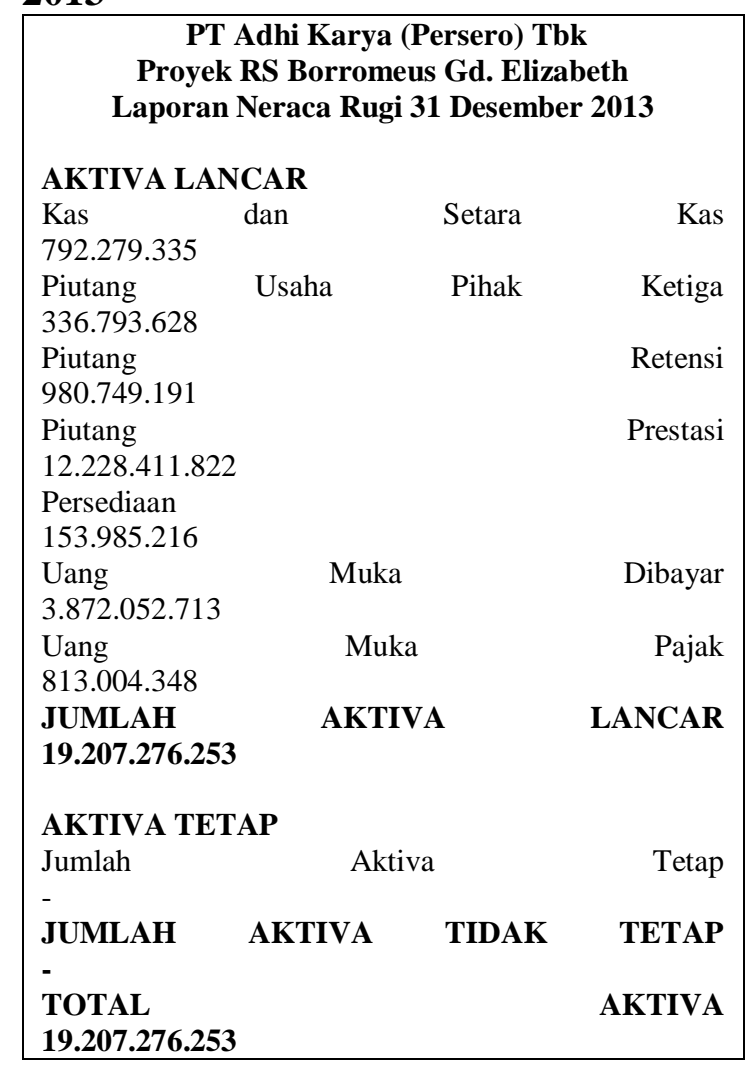

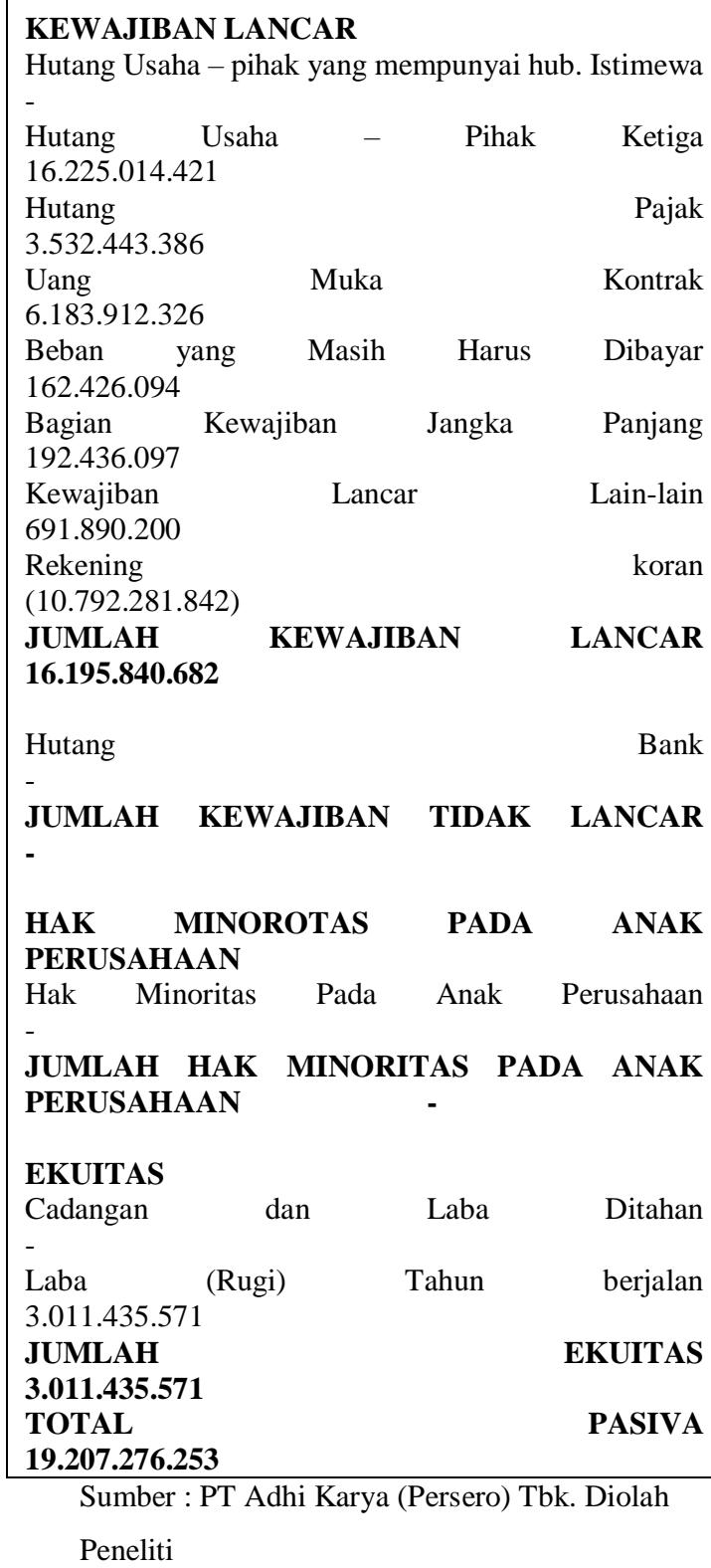

Tabel 9. Laporan Neraca Per Desember 2014

\begin{tabular}{|c|c|c|c|}
\hline \multicolumn{4}{|c|}{$\begin{array}{c}\text { PT Adhi Karya (Persero) Tbk } \\
\text { Proyek RS Borromeus Gd. Elizabeth } \\
\text { Laporan Neraca Rugi } 31 \text { Desember } 2014 \\
\text { AKTIVA LANCAR }\end{array}$} \\
\hline $\begin{array}{l}\text { Kas } \\
5.173 .131\end{array}$ & dan & Setara & Kas \\
\hline $\begin{array}{l}\text { Piutang } \\
348.673 .931\end{array}$ & Usaha & Pihak & Ketiga \\
\hline $\begin{array}{l}\text { Piutang } \\
2.477 .178 .151\end{array}$ & & & Retensi \\
\hline $\begin{array}{l}\text { Piutang } \\
800.099 .889\end{array}$ & & & Prestasi \\
\hline
\end{tabular}


JURNAL AKUNTANSI DAN BISNIS KRISNADWIPAYANA DOI: http://dx.doi.org/10.35137/jabk.v7i3.448

Vol. 7 No. 3 (September - Desember) 2020

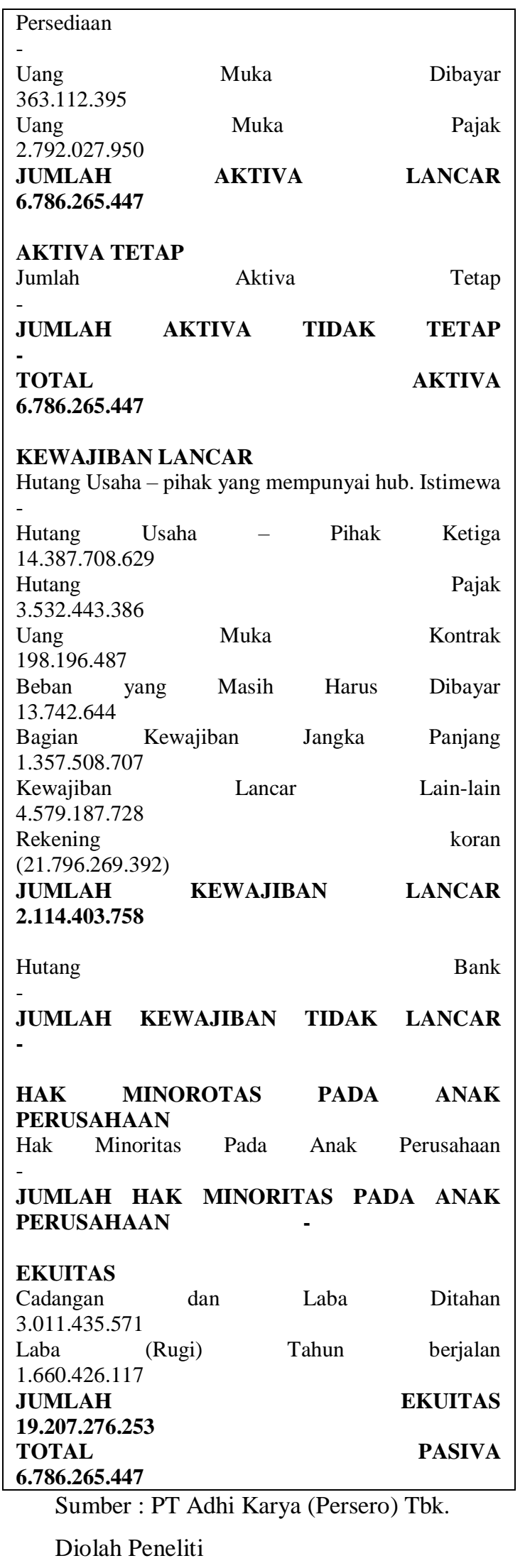

Tabel 10. Laporan Neraca Per Desember 2015

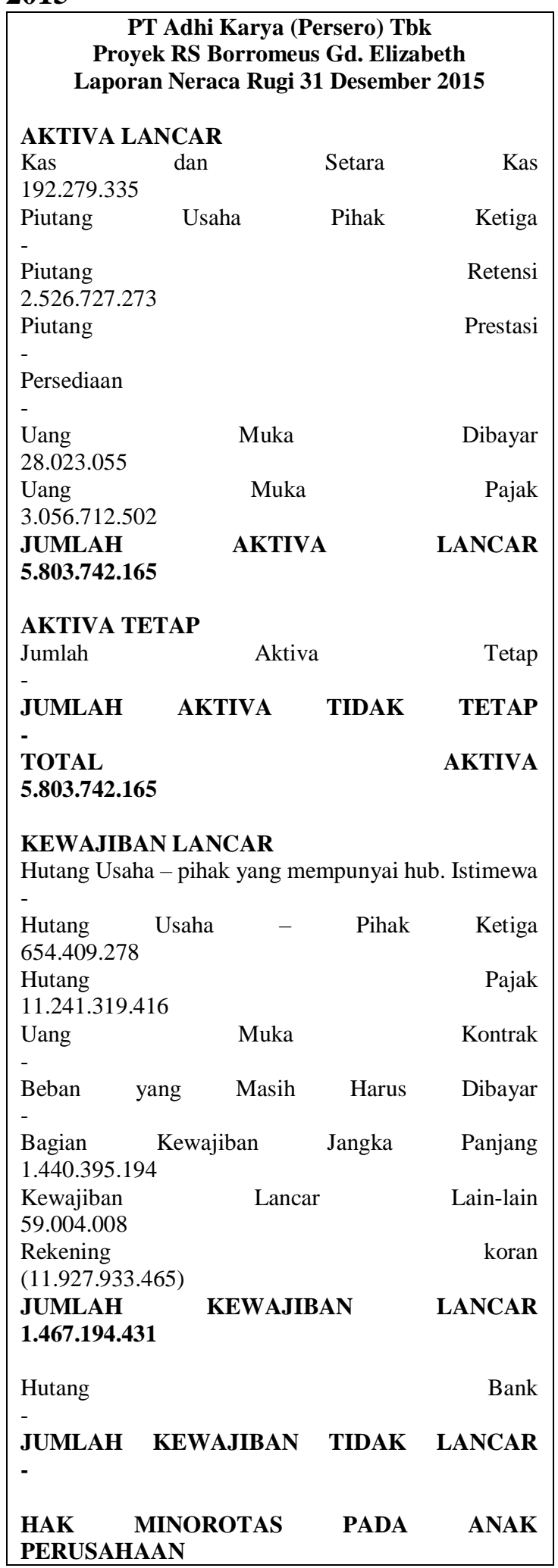


ISSN : $2406-7415$

e-ISSN : $2655-9919$

JURNAL AKUNTANSI DAN BISNIS KRISNADWIPAYANA

DOI: http://dx.doi.org/10.35137/jabk.v7i3.448

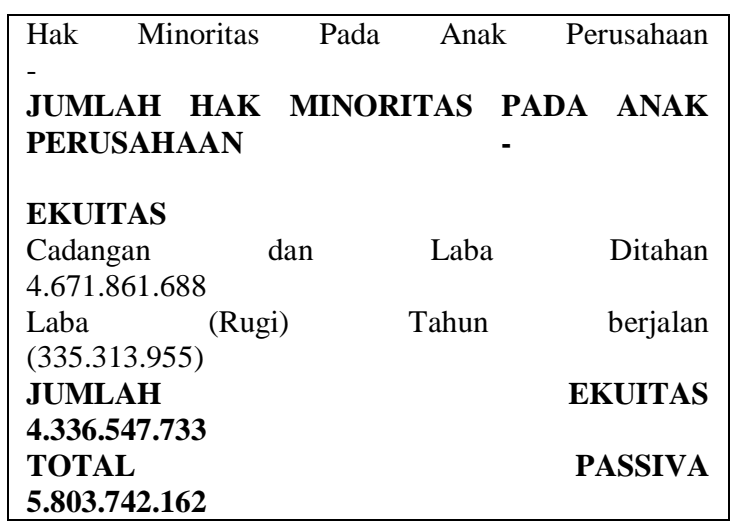

Tabel 11. Summary Pengakuan PPh Pasal 4 ayat 2 PT Adhi Karya (Persero) Tbk. Proyek RS Borromeus Gd. Elizabet

\begin{tabular}{|c|c|c|c|c|c|c|c|}
\hline \multicolumn{3}{|c|}{ Pencatatan } & \multicolumn{3}{|c|}{ Actual } & \multirow{2}{*}{$\begin{array}{l}\text { Selisi } \\
\text { h } \\
\text { PPh }\end{array}$} & \multirow[b]{2}{*}{$\begin{array}{l}\text { Ke } \\
\text { ter } \\
\text { an } \\
\text { ga } \\
\text { n }\end{array}$} \\
\hline $\begin{array}{c}\text { Tahu } \\
\text { n }\end{array}$ & $\begin{array}{c}\text { Pend } \\
\text { apata } \\
\text { n }\end{array}$ & PPh & $\begin{array}{c}\text { Tahu } \\
\text { n }\end{array}$ & $\begin{array}{c}\text { Pen } \\
\text { dap } \\
\text { ata } \\
\text { n }\end{array}$ & PPh & & \\
\hline $\begin{array}{l}2013 \\
2014 \\
2015\end{array}$ & $\begin{array}{r}25.54 \\
4.701 \\
.333 \\
24.01 \\
7.634 \\
.809 \\
954.0 \\
80.48 \\
5\end{array}$ & $\begin{array}{r}744.5 \\
69.40 \\
8 \\
673.4 \\
43.03 \\
1 \\
26.77 \\
5.622\end{array}$ & $\begin{array}{l}2013 \\
2014 \\
2015\end{array}$ & $\begin{array}{r}25.9 \\
11.5 \\
19.9 \\
61 \\
24.1 \\
28.1 \\
44.7 \\
48 \\
954 . \\
080 . \\
485\end{array}$ & $\begin{array}{r}377.75 \\
0.780 \\
562.93 \\
3.092 \\
504.10 \\
4.189\end{array}$ & $\begin{array}{r}366.8 \\
18.62 \\
8 \\
110.5 \\
09.93 \\
9 \\
-\end{array}$ & $\begin{array}{l}\text { Bl } \\
\mathrm{m} \\
\text { Ter } \\
\text { cat } \\
\text { at } \\
\text { Bl } \\
\mathrm{m} \\
\text { Ter } \\
\text { cat } \\
\text { at }\end{array}$ \\
\hline & $\begin{array}{r}50.53 \\
4.545 \\
.455\end{array}$ & $\begin{array}{r}1.444 \\
.788 \\
061\end{array}$ & & $\begin{array}{r}50.9 \\
93.7 \\
45.1 \\
94\end{array}$ & $\begin{array}{l}1.444 .7 \\
88.061\end{array}$ & & \\
\hline
\end{tabular}

